\title{
PERANCANGAN MOTION GRAPHICS IKLAN LAYANAN MASYARAKAT : STOP TOLAK PEMAKAMAN KORBAN COVID-19
}

\author{
Luqman Wahyudi ${ }^{1}$, Monica Revias Purwa Kusuma ${ }^{2}$ \\ ${ }^{1,2}$ Desain Komunikasi Visual, Fakultas Rekayasa Industri dan Desain, Institut Teknologi Telkom Purwokerto \\ JI.D.I Panjaitan No.128 Purwokerto, 53147 \\ revias@ittelkom-pwt.ac.id
}

Received: 9 Januari 2021

Revised: 7 Juli 2021

Accepted: 10 Juli 2021

\begin{abstract}
Abstrak : Banyaknya korban jiwa akibat Covid-19 memicu kecemasan masyarakat yang besar terkait pemakaman korban Covid-19. Terdapat beberapa kasus penolakan jenazah korban Covid-19 di sejumlah daerah di Indonesia, salah satunya di Kabupaten Banyumas. Ketakutan serta kurangnya edukasi pada masyarakat tentang protokol pemakaman korban Covid-19 menjadi pemicu utama fenomena ini. Salah satu cara efektif mengedukasi masyarakat tentang penolakan pemakaman korban Covid-19 adalah dengan membuat Iklan Layanan Masyarakat (ILM) berwujud motion graphics. Jenis pendekatan penelitian yang dipilih dalam perancangan ini adalah metode kualitatif dengan teknik analisis data menggunakan $5 \mathrm{~W}+1 \mathrm{H}$ yaitu who, what, when, where, why, dan how. Perancangan iklan layanan masyarakat ini bertujuan untuk mengedukasi masyarakat agar tidak takut dan menolak jenazah korban Covid-19 untuk dimakamkan. Hasil perancangan menunjukkan bahwa penyampaian informasi mengenai penolakan jenazah korban Covid-19 dapat dilakukan menggunakan media motion graphics, yang melalui tiga tahapan yaitu praproduksi, produksi, dan pascaproduksi. Manfaat dari penelitian ini adalah menyampaikan informasi kepada masyarakat mengenai Standar Operasional Prosedur (SOP) pemulasaran jenazah korban Covid-19 agar dapat mengurangi kekhawatiran yang berlebih dan menghindari fenomena penolakan pemakaman jenazah korban Covid-19. Informasi tersebut sudah tersampaikan dengan baik kepada target audiens melalui iklan Instagram, Facebook, maupun YouTube, dilihat dari jangkauan media-media yang telah dipasangi iklan layanan masyarakat ini.

Kata kunci: iklan layanan masyarakat, Covid-19, motion graphics, penolakan pemakaman

Abstract : A large number of fatalities due to Covid-19 has triggered great public anxiety regarding the burial of Covid-19 victims. There have been several cases of funeral refusal of the Covid-19 victim bodies in many regions in Indonesia, such as in Kabupaten Banyumas. Fear and lack of education to the public about the funeral protocols for the Covid-19 victims were the main triggers for this incident. One of the effective ways to educate the public about the funeral refusal for Covid-19 victims is making Public Service Advertisements (PSAs) motion graphics. The research approach
\end{abstract}


chosen in this design is a qualitative method with data analysis techniques using $5 \mathrm{~W}$ $+1 H$, namely who, what, when, where, why, and how. The design of this public service advertisement aims to educate the public not to be afraid and to refuse the funeral of the Covid-19 victim bodies. The design results show that the delivery of information regarding the refusal of the Covid-19 victim bodies can be done using motion graphics media, which goes through three stages, namely preproduction, production, and postproduction. The benefit of this research is to convey information to the public about the Standard Operating Procedure (SOP) for covering the bodies of Covid-19 victims to reduce excessive worry and avoid the phenomenon of funeral refusal of the Covid-19 victim bodies. This information has been well conveyed to the target audience through Instagram, Facebook, and YouTube advertisements, as seen from the reach of the media installed with these public advertisements.

Keywords: Public Service Advertisements, Covid-19, motion graphics, funeral refusal

\section{PENDAHULUAN}

Akhir tahun 2019 dunia dikejutkan oleh salah satu virus yang menyerang masyarakat Wuhan yang merupakan sebuah kota di Provinsi Wubei, China. Virus tersebut dinamakan Covid-19 atau sering disebut dengan virus Corona. Covid-19 adalah suatu virus yang menyerang sistem pernapasan dan mirip dengan virus SARS. Sistem pernapasan yang telah terinfeksi oleh Covid-19 membuat pasien mengalami pnemonia pada organ paru-paru. Covid-19 memiliki beberapa gejala yang muncul antara lain seperti demam tinggi, batuk pilek, gangguan pernapasan, dan sakit tenggorokan (Banjarnahor, 2020: 362). Penyebaran virus ini sangat cepat karena bisa tersebar dari manusia ke manusia melalui percikan atau droplet. Saat ini Covid-19 sudah menyerang banyak masyarakat di seluruh dunia dan dinyatakan oleh WHO sebagai pandemi. Karena belum ditemukan obat spesifik ataupun vaksin untuk Covid-19, maka pemerintah Indonesia membuat Pembatasan Sosial Berskala Besar (PSBB) di mana masyarakat dihimbau untuk bekerja, bersekolah, maupun beribadah di rumah sampai pandemi ini mereda. Selain itu, pemerintah menghimbau agar masyarakat memakai masker ketika keluar rumah dan menerapkan jarak aman (1 meter) ketika bertemu orang lain, serta tidak bersentuhan secara fisik. Semua 
kebijakan pemerintah yang diterapkan terkait Covid-19 ini diharapkan mampu mengontrol penyebaran virus tersebut.

Sampai saat ini (22 April 2020), masyarakat yang terserang Covid-19 sudah menyentuh angka 7.418 yang terdiri dari 5.870 pasien yang dirawat, 635 meninggal, dan 918 orang telah sembuh. Angka kematian saat ini kurang lebih di angka 8\%, sedangkan angka kesembuhan sekitar 13\%. Daerah terbanyak dengan pasien yang terinfeksi ada di DKI.Jakarta yaitu 11.680 orang (Satuan Tugas Penanganan COVID-19, 2020).

Banyaknya kasus masyarakat yang meninggal dikarenakan Covid-19 membuat warga yang masih sehat mengalami kecemasan. Hal ini memicu penolakan terhadap pemakaman jenazah Covid-19 dari warga di berbagai daerah, terutama yang tinggal di sekitar pemakaman. Hal ini bertentangan Undang-undang Nomor 4 tahun 1984 tentang wabah penyakit menular yang mengatakan bahwa tindakan yang mengganggu upaya penanggulangan wabah adalah bertentangan dengan hukum dan dikenakan sanksi pidana (Badan Pembinaan Hukum Nasional, 1984).

Hal yang sama juga terjadi di Banyumas, kasus tersebut bermula dari seorang korban Covid-19 yang meninggal di Purwokerto dan akan dimakamkan, tetapi warga setempat menolak pemakaman korban Covid-19 tersebut. Jenazah tersebut ditolak beberapa kali, sampai pada akhirnya akan dimakamkan di Desa Pakuncen, Kabupaten Banyumas. Akan tetapi, warga desa tersebut pun juga melakukan penolakan yang sama. Bupati Banyumas Achmad Husein sendiri prihatin dengan adanya penolakan tersebut sehingga dirinya ikut membongkar makam korban dan memindahkannya ke tempat lain (Zain, 2020). Aksinya tersebut dilandasi inginnya menunjukkan kepada masyarakat bahwa korban Covid-19 yang sudah meninggal tidak akan membawa virus lagi. 
Kejadian penolakan jenazah korban Covid-19 membuat keprihatinan tersendiri bagi pemerintah ataupun masyarakat yang memiliki rasa empati yang tinggi. Alasan utama adanya penolakan pemakaman jenazah Covid-19 ini dikarenakan kurangnya pengetahuan masyarakat terhadap hal-hal yang berkaitan dengan Covid-19 serta tidak adanya sosialisasi kepada warga sekitar. Oleh sebab itu muncul kekhawatiran akan terjadinya penularan virus Covid-19 yang berasal dari jenazah Covid-19 kepada warga masyarakat sekitar lokasi pemakaman (Manihuruk, 2020: 41).

Penolakan tersebut tidak akan terjadi jika masyarakat teredukasi tentang protokol pemakaman Covid-19 dan informasi mengenai tidak adanya penularan virus tersebut jika korban sudah meninggal. Salah satu cara mengedukasi atau memberikan penyuluhan terhadap masyarakat tentang penolakan pemakaman korban Covid-19 adalah dengan membuat Iklan Layanan Masyarakat (ILM). Iklan sendiri merupakan sarana yang efektif untuk menyampaikan pesan kepada khalayak ramai (Kasali, 2007: 11). Sedangkan iklan layanan masyarakat adalah Iklan yang digunakan untuk menyampaikan informasi, mengajak dan mengedukasi khalayak dengan tujuan bukan komersil, berisi tentang pesan-pesan sosial non profit (Pujiyanto, 2013: 8).

Iklan Layanan Masyarakat (ILM) yang berjudul "Stop Tolak Pemakaman Korban Covid-19!" ini menggunakan teknik motion graphics yang berisi konten edukasi tentang masalah tersebut. Motion graphics adalah sebuah karya audio visual yang merupakan gabungan dari ilustrasi, tipografi, fotografi, dan videografi dengan menggunakan teknik-teknik animasi. Octavia dan Fadilla (2017) menjelaskan bahwa motion graphics merupakan media informasi yang bertujuan untuk memberikan pemahaman melalui video ilustrasi berupa animasi dalam melakukan pendekatan terhadap khalayak sasaran. Sedangkan Wardhani dan Sudjudi (2014:3) dalam jurnalnya menjelaskan: "Motion graphics adalah grafis yang memanfaatkan video dan 
atau animasi untuk menciptakan ilusi gerakan atau transformasi. Desain grafis telah berkembang dari sebuah publikasi statis menjadi publikasi yang lebih dinamis dengan memanfaatkan teknologi komunikasi seperti animasi, film, media interaktif serta desain lingkungan".

Iklan Layanan Masyarakat sendiri sudah banyak yang menggunakan motion graphics karena dianggap sebagai media yang lebih menarik dalam menyampaikan suatu pesan, sehingga masyarakat lebih tertarik untuk mengetahui informasi apa yang akan disampaikan. Perancangan iklan layanan masyarakat yang pernah dirancang sebelumnya banyak yang menggunakan motion graphics menjadi media penyampai pesan. Namun, belum ada yang mengangkat mengenai fenomena penolakan pemakaman korban Covid-19.

Beberapa contoh perancangan iklan layanan masyarakat sebelumnya yang menggunakan motion graphics yaitu penelitian Rahmat Rahmando yang berjudul Perancangan Iklan Layanan Masyarakat Keselamatan di Perlintasan Kereta Api dalam Media Motion Graphics (Rahmando, Syafwandi dan Trinanda, 2018). Hasil penelitian ini berupa karya motion graphics dan material pendukung yang bertujuan mengingatkan target audience agar peduli dengan keselamatan di perlintasan kereta api.

Terdapat pula penelitian Rayhan Helsa Fajri yang berjudul Perancangan Motion Graphics Sebagai Iklan Layanan Pentingnya Imunisasi Bagi Anak Sejak Usia Dini di Kota Bukittinggi (Fajri, Zubaidah dan Pebriyeni, 2018). Hasil penelitian ini berupa karya motion graphics sebagai media penyuluhan yang bertujuan mengingatkan target audience di Bukittinggi agar menyadari dampak tidak melakukan imunisasi bagi anak usia dini.

Dilihat dari beberapa referensi yang sudah ditinjau, belum ada penelitian spesifik yang menyinggung fenomena Covid-19 terutama mengenai penolakan pemakaman jenazah korban dan mengangkatnya menjadi karya 
motion graphics. Hal tersebut dikarenakan pandemi Covid-19 merupakan fenomena baru di Indonesia yang terjadi di tahun 2020.

Iklan Layanan Masyarakat (ILM) yang berjudul "Stop Tolak Pemakaman Korban Covid-19!" nantinya dapat diunggah di channel Youtube, ataupun disebarkan via media sosial seperti Instagram dan Facebook. Berdasarkan uraian latar belakang masalah di atas, maka dirumuskan suatu permasalahan yaitu bagaimana merancang motion graphics Iklan Layanan Masyarakat : Stop Tolak Pemakaman Korban Covid-19? Dengan perancangan iklan layanan masyarakat ini, penulis berharap dapat membantu sosialisasi dan edukasi mengenai proses pemakaman korban Covid-19.

\section{METODE PENELITIAN}

Metode desain yang digunakan pada perancangan ini termasuk pada kategori metode desain baru, di mana proses perancangan dilaksanakan dalam sebuah tim yang anggotanya memiliki kewajiban berbeda-beda dan pengerjaannya pun dapat dilaksanakan secara terpisah. Hal tersebut sering disebut sebagai design team ataupun kelompok desainer (Sarwono dan Lubis, 2007: 8).

Jenis pendekatan penelitian yang dipilih dalam perancangan ini adalah metode kualitatif. Penelitian dengan metode pendekatan kualitatif tidak menggunakan angka namun melalui pengumpulan data, analisis, dan diinterpretasikan (Anggito dan Setiawan, 2018: 9). Melalui metode ini diharapkan penulis dapat memperoleh informasi yang mendalam mengenai obyek yang diteliti. Data-data kualitatif pada perancangan ini diperoleh dari literatur dan dokumentasi dikarenakan terbatasnya ruang dan waktu penulis untuk terjun langsung ke lapangan di saat keadaan pandemi Covid-19. Metode dokumentasi ini dapat digunakan untuk mendapat gambaran dari 
sudut pandang subjek melalui suatu media tertulis dan dokumen lain yang dibuat langsung oleh subjek yang bersangkutan (Herdiansyah, 2010: 143). Penelitian ini tunduk pada batasan waktu, sehingga peneliti harus menggunakan prosedur pengumpulan data dalam jangka waktu tertentu untuk mengumpulkan informasi yang rinci.

Teknik analisis data yang digunakan menggunakan teknik pertanyaan 5W $1 \mathrm{H}$ yaitu what, who, when, where, why, dan how (teknik pertanyaan: apa, siapa, kapan, di mana, mengapa, dan bagaimana) (Zikmund dan Babin, 2011: 85) untuk dijadikan pendekatan penelitian yang mendukung perancangan ini. Untuk menjawab what atau seperti apa perancangannya pada perancangan ini adalah iklan layanan masyarakat yang akan dibuat ini berbentuk motion graphics, di mana nantinya ada cerita yang diangkat sebagai bahan edukasi masyarakat mengenai fenomena penolakan jenazah korban Covid-19. Motion graphics ini juga akan dilengkapi voice over untuk mendukung penjelasan selain melalui gambar dan tulisan.

Untuk menjawab who atau siapa target audience dari perancangan ini adalah masyarakat Indonesia, pria dan wanita, berumur 17-55 tahun, dan memiliki pendidikan SMP sampai perguruan tinggi. Target audiene ini dipilih karena pada jenjang umur tersebut seseorang cenderung produktif dan mengikuti perkembangan berita pada saat ini. Dengan hal tersebut masyarakat ini dapat membagikan pengetahuan tersebut ke masyarakat lain agar informasi dapat menyebar secara lebih luas lagi.

Untuk menjawab where atau di mana ditayangkan iklan layanan masyarakat ini yaitu dapat ditayangkan melalui Youtube, Instagram, maupun Facebook. Platform tersebut dipilih karena memiliki sifat shareable atau dapat dibagikan ke masyarakat secara lebih luas lagi.

Untuk menjawab when atau kapan iklan layanan masyarakat ini diluncurkan yaitu akan diluncurkan saat masa pandemi Covid-19 yaitu akhir 
tahun 2020. Waktu tersebut dipilih karena pandemi Covid-19 pada saat itu belum juga selesai bahkan malah semakin parah.

Untuk menjawab why atau mengapa motion graphics dipilih yaitu karena memiliki kekuatan untuk membuat cerita sesuai dengan konsep yang direncanakan. Media tersebut juga merupakan media yang cocok untuk mendiskripsikan sesuatu informasi karena lebih dinamis dan atraktif sehingga dapat menarik perhatian masyarakat.

Untuk menjawab how atau bagaimana cara merancangnya yaitu menggunakan tiga tahapan produksi yang penting dalam pembuatan motion graphics yaitu praproduksi, produksi, dan pascaproduksi (Mahardhika dan Anam Fathoni, 2013: 1185). Pengerjaan motion graphics dimulai dari proses praproduksi yaitu peneliti merancang konsep dari mencari inspirasi dengan studi visual, mengembangkan ide, merencanakan style, membuat storyboard dan storyline. Lalu akan dilanjutkan ke dalam proses produksi produk yaitu pembuatan ilustrasi untuk aset motion graphics, merealisasikan dengan cara digitalisasi menggunakan software grafis seperti Adobe Photoshop, Adobe Ilustrator, dan Adobe After Effect. Setelah proses produksi jadi lalu dilanjutkan proses pascaproduksi yakni pengisian voice over, finishing, dan yang terakhir proses rendering menjadi video.

Gambar 1 merupakan bagan alur perancangan Iklan Layanan Masyarakat "Stop Tolak Pemakaman Korban Covid-19". 
1

\begin{tabular}{|l|}
\hline \multicolumn{1}{|c|}{ Pengumpulan Data } \\
\hline 1. Studi Pustaka : \\
a. Pandemi Covid-19 di \\
dunia dan di Indonesia. \\
b. Fenomena penolakan \\
korban Covid-19. \\
2. Dokumentasi : \\
a. Dokumen SOP \\
Pemulasaran Jenazah \\
Covid-19 \\
b. Dokumen angka \\
Covid-19.
\end{tabular}

2

\begin{tabular}{|l|}
\hline \multicolumn{1}{|c|}{ Analisis Data } \\
\hline 1. What? \\
Seperti Apa \\
Perancangannya? \\
2. Who? \\
Siapa Target Audiensnya? \\
3. Where? \\
Di mana ditayangkan? \\
4. When? \\
Kapan diluncurkan? \\
5. Why? \\
Mengapa motion graphic? \\
6. How? \\
Bagaimana merancangnya? \\
\end{tabular}

Gambar 1. Bagan Alur Perancangan Sumber: Dokumentasi penulis

\section{3}

\begin{tabular}{|l|}
\hline \multicolumn{1}{|c|}{ Perancangan } \\
\hline 1. Tahap Pra-produksi \\
a. Mencari inspirasi untuk \\
merancang konsep \\
dengan studi visual. \\
b. Mengembangkan ide \\
dengan brainstorming. \\
c. Membuat story board. \\
2. Tahap Produksi \\
a. Pembuatan ilustrasi \\
b. Proses digitalisasi dan \\
pembuatan motion \\
graphic. \\
3. Tahap Pasca Produksi \\
a. Pengisian voice over \\
b. Finishing \\
c. Rendering \\
\hline
\end{tabular}

a. Mencari inspirasi untuk merancang konsep dengan studi visual.

b. Mengembangkan ide dengan brainstorming.

c. Membuat story board

2. Tahap Produksi

a. Pembuatan ilustras

b. Proses digitalisasi dan

3. Tahap Pasca Produksi

a. Pengisian voice over

Finishing

c. Rendering

\section{HASIL DAN DISKUSI}

\section{Tahap Praproduksi}

Tahap pertama dalam perancangan ini di mulai dengan pencarian Inspirasi. Pada tahapan ini, tim desainer mencari referensi-referensi yang sudah ada dengan objek yang sama yaitu iklan layanan masyarakat yang menggunakan teknik motion graphics tetapi berbeda tema dengan rencana perancangan ini. Referensi tersebut dicari melalui Internet pada media Youtube.

Tahap kedua yaitu brainstorming yang merupakan tahapan mengumpulkan gagasan-gagasan tim desain dan merumuskan gagasan yang 
dianggap tepat untuk dilanjutkan ke tahap perencanaan style, perancangan storyboard dan storyline. Brainstorming merupakan cara terbaik dalam menggali ide atau gagasan sekaligus menyeleksi untuk mendapatkan hasil terbaik. Hal ini sejalan dengan pendapat J. Geoffrey Rawlinson yang beranggapan bahwa "Brainstorming is probably the best known of all the techniques available for creative problem solving" (Rawlinson, 2017: 66). Pada tahapan ini didapatkan beberapa gagasan yang akan diterapkan pada proses perancangan selanjutnya.

Hal yang ditentukan selanjutnya yaitu menentukan pesan verbal. Pesan verbal yang akan disampaikan yaitu keamanan proses pemulasaran jenazah Covid-19 yang sudah sesuai SOP. Dengan mengetahui proses yang sudah sesuai dengan prosedur, diharapkan masyarakat sudah tidak lagi menolak pemakaman jenazah Covid-19 di daerah mereka masing-masing.

Gaya visual merupakan hal yang penting dalam perancangan ini. Gaya visual untuk dari karakter maupun visualisasi beberapa scene dibuat menggunakan style gambar kartun 2 dimensi. Hal ini terlihat dari ciri-ciri gambar dalam scene yang mengalami penyederhanaan, lebih ekspresif, dan tidak sesuai pakem proporsi dan anatomi ideal (McCloud, 2001: 54). Hal ini juga didukung oleh penelitian terbaru yang berpendapat bahwa sebuah ilustrasi tidak hanya menjadi elemen untuk menarik perhatian masyarakat, melainkan dapat memandu konten edukasi yang disampaikan (Nadya dan Erlyana, 2020: 367). Tahap ini dimulai dengan membuat sketsa kasar yang juga digunakan pada storyboard, kemudian didigitalkan menggunakan software Adobe Photoshop dengan bantuan pen tablet.

Warna dapat memberikan kesan dan identitas tertentu sesuai dengan kondisi sosial bahkan psikologis orang yang melihat (Patrycia, 2013: 31). Warna yang digunakan pada perancangan ini yaitu campuran warna-warna dingin (biru, hijau, abu-abu) dengan warna-warna panas (merah, orange, 
kuning). Hal ini disesuaikan dengan karakter scene yang ditampilkan. Warnawarna yang digunakan lebih mengarah pada warna-warna solid yang strong dan terlihat jelas agar lebih menarik dilihat.

Tipografi memiliki peran yang sangat penting dalam sebuah desain sebagai media komunikasi. Tipografi mengatur dan mengolah huruf baik dari segi artistik maupun fungsional (keterbacaan) untuk kepentingan komunikasi (Hananto, 2020: 135). Tipografi yang dipilih adalah tipe huruf san sherif karena memiliki keterbacaan yang tinggi jika digunakan pada motion graphics yang cenderung memiliki pergerakan yang lumayan cepat. Font yang digunakan yaitu Montserrat dan American Captain (Gambar 2).

\section{MONTSERRAT}

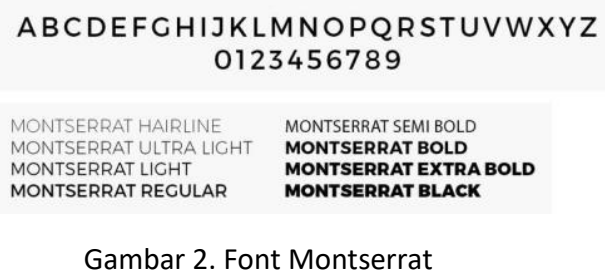

Gambar 2. Font Montserrat

Sumber: https://id.pinterest.com/pin/377880224976515876/, 2020

Suara yang digunakan pada perancangan ini adalah non-diegitic yaitu pengisi suara tidak tampil pada video tetapi hanya suaranya yang dipakai. Biasanya metode pengisian suara ini biasa disebut teknik voice over atau narasi suara. Pada perancangan ini durasi video nantinya akan dibuat sekitar 1 menit agar konten dapat tersampaikan dengan singkat, padat, dan jelas.

Tahapan storyboard adalah tahapan membuat alur cerita dan sketsa kasar per adegan yang akan dibuat. Pembuatan storyboard dilakukan oleh tim desain yang bertugas untuk menuangkan ide cerita ke dalam sketsa kasar berbentuk storyboard (Tabel 1). 
Tabel 1. Storyboard

\begin{tabular}{|c|c|c|c|c|}
\hline Scene & Adegan & Menit & Durasi & Naskah \\
\hline 1 & & 00.01 & $3^{\prime \prime}$ & $\begin{array}{l}\text { Rona dan Koron bertemu di taman, lalu Koron } \\
\text { bercerita bahwa dirinya mendengar cerita } \\
\text { tentang temannya Deka yang meninggal dan } \\
\text { ditolak jenazahnya saat akan dimakamkan. }\end{array}$ \\
\hline 2 & & 00.3 & $2^{\prime \prime}$ & $\begin{array}{l}\text { (Dalam bayangan Rona yang bercerita) } \\
\text { Pasien covid-19 di tempat tidur }\end{array}$ \\
\hline 3 & & 00.5 & $2^{\prime \prime}$ & $\begin{array}{l}\text { (Dalam bayangan Rona yang bercerita) } \\
\text { Fokus ke garis di Monitor menjadi lurus tanda } \\
\text { orang tsb sudah meninggal }\end{array}$ \\
\hline 4 & & 00.7 & $2^{\prime \prime}$ & $\begin{array}{l}\text { (Dalam bayangan Rona yang bercerita) } \\
\text { Peti mati di dorong ke ambulance oleh petugas } \\
\text { dengan pakaian APD. }\end{array}$ \\
\hline 5 & & 00.9 & $4^{\prime \prime}$ & $\begin{array}{l}\text { (Dalam bayangan Rona yang bercerita) } \\
\text { Ambulance berjalan ke kuburan } \\
\text { Di tengah jalan dicegat sama orang2 dan } \\
\text { dilempari batu }\end{array}$ \\
\hline 6 & & 00.13 & $5^{\prime \prime}$ & $\begin{array}{l}\text { Muncul tanda Stop! Penolakan jenazah korban } \\
\text { Covid-19 }\end{array}$ \\
\hline 7 & & 00.18 & $38^{\prime \prime}$ & $\begin{array}{l}\text { Gambar kaki jenazah (dibuat infografis). } \\
\text { Jenazah tidak akan menularkan penyakitnya } \\
\text { karena : } \\
\text { - } \quad \text { SOP pemulasaran jenazah sudah sesuai anjuran } \\
\text { WHO. } \\
\text { - } \quad \text { Jenazah telah dimandikan sesuai ketentuan. } \\
\text { - } \quad \text { Jenazah dibungkus kain kafan, dibungkus plastik } \\
\text { kedap, diikat,dan dimasukkan ke dalam kantong } \\
\text { jenazah lalu juga di desinfektan. } \\
\text { - Jenazah dimasukkan dalam peti kedap, } \\
\text { dimasukkan ke plastik lalu di desinfektan } \\
\text { kembali. } \\
\text { - Peti mati tidak akan dibuka kembali dan } \\
\text { dimakamkan bersama jenazah. } \\
\text { - Jenazah disemayamkan tidak lebih dari } 4 \text { jam } \\
\text { - Jenazah dikubur sedalam minimal 1,5m dan } \\
\text { ditutup tanah setinggi } 1 \mathrm{~m} \text {. }\end{array}$ \\
\hline 8 & & 00.56 & $4^{\prime \prime}$ & $\begin{array}{l}\text { Stop Penolakan Pemakaman Jenazah korban } \\
\text { Covid } 19 ! \\
\text { Fokus pada Protocol kesehatan diri sendiri! }\end{array}$ \\
\hline 9 & $\lim _{x \rightarrow \infty}$ & 01.00 & $5^{\prime \prime}$ & $\begin{array}{l}\text { Iklan Layanan Masyarakat dipersembahkan } \\
\text { oleh Desain Komunikasi Visual Institut } \\
\text { Teknologi Telkom Purwokerto }\end{array}$ \\
\hline
\end{tabular}

Sumber: Dokumentasi penulis 


\section{Tahapan Produksi}

Tahapan selanjutnya yang dilakukan setelah melakukan tahapan praproduksi adalah tahapan produksi. Pada tahapan ini tim desain mulai membuat ilustrasi sesuai dengan urutan cerita pada storyboard yang dibuat (Tabel 2).

Tabel 2. Visualisasi scene berdasarkan storyboard

Scene Visualisasi Keterangan

1

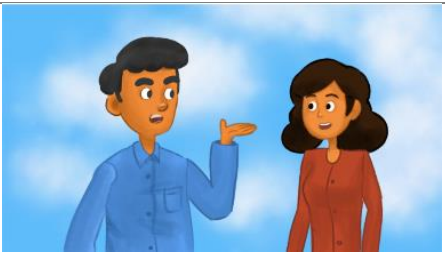

2

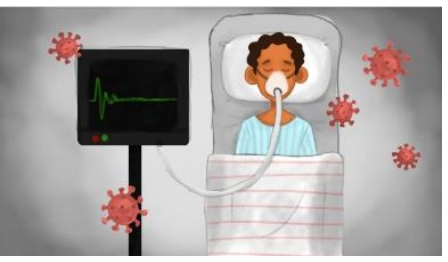

3

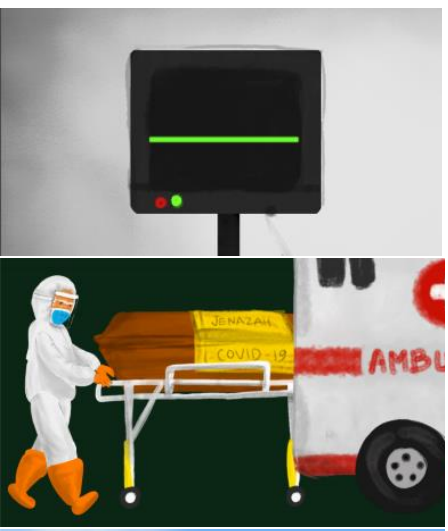

5

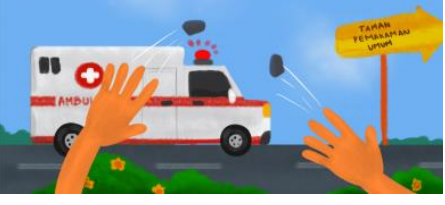

Scene 1 merupakan awal cerita dari iklan layanan masyarakat ini yaitu pembangunan cerita mengenai fenomena yang terjadi yaitu penolakan pemakaman jenazah korban Covid-19. Di scene ini Koron bercerita tentang Deka temannya yang meninggal karena Covid-19.

Scene 2 yang menggambarkan cerita tentang Deka yang terkena Covid-19 dan dirawat di rumah sakit.

scene 3 menggambarkan Deka yang meninggal karena terkena Covid-19. Layar yang menampilkan garis lurus merupakan tanda bahwa pasien sudah meninggal.

scene 4 menggambarkan saat jenazah Deka dimasukkan ke ambulans untuk berangkat ke pemakaman.

scene 5 menggambarkan saat ambulans berjalan menuju ke taman pemakaman umum. Inilah scene yang menggambarkan mengenai fenomena tentang penolakan jenazah untuk dimakamkan di taman pemakaman umum. Yang terjadi di kota-kota di Indonesia termasuk Banyumas. 
6

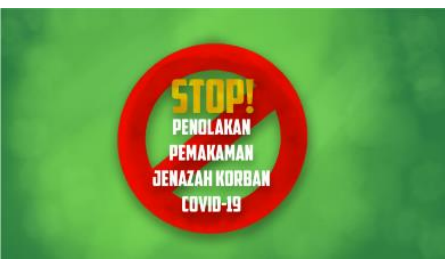

7

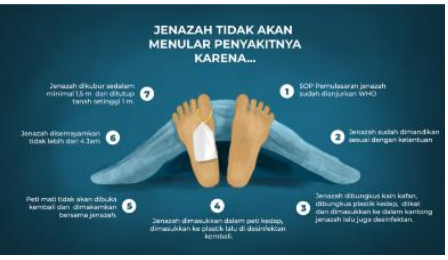

8

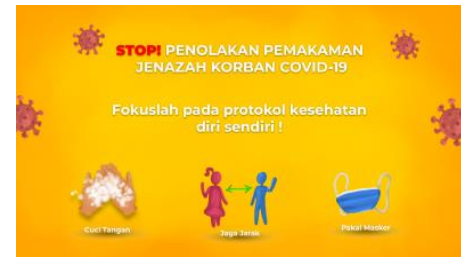

9

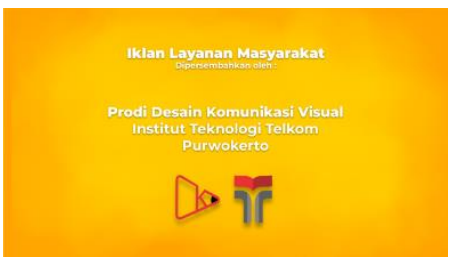

scene 6 yang menggambarkan tanda stop yang disertai larangan yang berbunyi "Stop!

Penolakan Pemakaman Jenazah Covid-19". Larangan ini merupakan informasi penting yang harus tersampaikan kepada target audience.

scene 7 yang memberikan informasi tentang jenazah Covid-19 tidak akan menularkan penyakitnya karena dalam penanganannya sudah menaati SOP yang ditetapkan. Scene ini bisa menjadi informasi tambahan kepada target audience agar semakin yakin untuk tidak mengkhawatirkan jenazah korban Covid-19 yang dimakamkan di sekitarnya.

scene 8 yang memberikan himbauan ulang yang berbunyi "Stop! Penolakan Pemakaman Jenazah Covid-19" serta meminta pada target audiens untuk fokus menaati protokol kesehatan diri sendiri yaitu cuci tangan, jaga jarak, dan pakai masker.

scene 9 yang memberikan informasi mengenai Iklan Layanan Masyarakat yang dibuat dengan dukungan Prodi Desain Komunikasi Visual Institut Teknologi Telkom Purwokerto.

Sumber: Dokumentasi pribadi

\section{Tahapan Pascaproduksi}

Pada tahapan pascaproduksi ini penulis bersama tim melakukan finishing yaitu melakukan penggabungan per-scene berdasarkan durasi pengisian suara dengan teknik voice over, dan memberi efek suara maupun musik pendukung. Setelah semua itu selesai baru dilakukan rendering sesuai output yang diharapkan yaitu MP4 video dengan resolusi 1920 x 1080. Di tahapan ini pula penulis selanjutnya akan mendistribusikan ke media-media sosial. Tahapan pendistribusian ke media sosial ini juga berfungsi sebagai bentuk verifikasi. Tahapan verifikasi ini merupakan salah satu tahapan dalam metode perancangan 
glass box yang terdiri dari tahap perencanaan, inkubasi, iluminasi, dan verifikasi. Metode glass box ini digunakan pada penelitian terdahulu dalam iklan layanan masyarakat berbentuk motion graphics tentang nomophobia (Perdana dan Zubaidah, 2020: 4). Metode ini jarang digunakan dalam penciptaan suatu karya dan lebih umum digunakan untuk menggali proses kreatif dari si pengkarya atau kreator. Namun penggunaan metode ini cukup relevan digunakan sebagai alternatif dari tahap proses praproduksi, produksi, dan pascaproduksi yang penulis gunakan. Tahapan verifikasi sendiri merupakan pengujian atas karya yang telah diwujudkan langsung pada dunia nyata (Aprilia, Iswidayati dan Triyanto, 2019: 245). Tahapan ini sangat relevan digunakan untuk mengetahui efektivitas dan jangkauan video ILM penolakan jenazah korban Covid-19 di masyarakat.

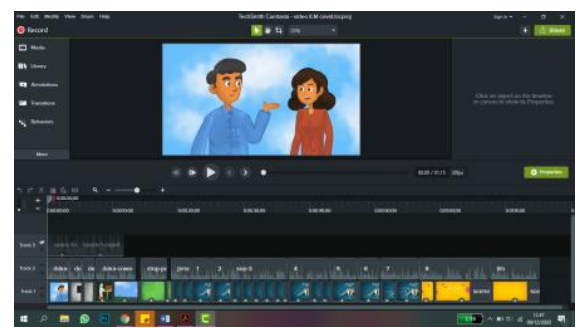

Gambar 3. Proses Penggabungan Scene dan Pengisian Suara Sumber: Dokumentasi penulis

Media sosial yang digunakan sebagai media publikasi video ILM ini adalah Youtube, Facebook, dan Instagram. Youtube sendiri merupakan sebuah website dan aplikasi untuk mengunggah informasi berupa video. Video yang diunggah di Youtube dapat menjangkau seluruh dunia dan dapat diakses melalui website atau aplikasi handphone. Konten-konten yang diunggah pada Youtube biasanya berisi tentang video blog, video musik, video hiburan, video animasi termasuk motion graphics. Youtube dipilih karena merupakan aplikasi yang banyak digunakan oleh target audience perancangan ini, selain itu informasi yang ditayangkan melalui Youtube juga lebih cepat untuk disebarkan karena memiliki fitur share ke aplikasi lain seperti aplikasi chatting. 
Facebook adalah sebuah website yang digunakan sebagai media jejaring sosial dan memiliki pengguna terbanyak di Indonesia. Facebook memungkinkan seseorang membagikan aktivitas harian yang berbentuk teks, foto, maupun video. Facebook dipilih karena dapat mempromosikan unggahan melalui FB Ads yang bisa memilih target sesuai segmentasi yang sudah ditetapkan. Instagram adalah sebuah aplikasi berbagi foto maupun video yang juga memungkinkan pengguna untuk mencari teman melalui aplikasi tersebut. Instagram dipilih karena dapat menarget segmentasi sesuai target audience yang ditetapkan dengan menggunakan fitur Instagram Ads. Dengan media-media yang dipilih sebagai alat untuk mendistribusikan karya perancangan, diharapkan informasi dapat tersampaikan secara baik dan cepat.

Pada media Facebook, iklan layanan masyarakat ini per 15 Maret 2021 telah dijangkau oleh 137.175 orang dengan 4.981 engagement. Sedangkan pada Instagram, iklan layanan masyarakat ini telah dijangkau 34.460 orang. Hal ini membuktikan bahwa penggunaan media sosial sangat efektif menjangkau audience dengan skala yang besar dan sesuai dengan target audiens yang telah ditentukan.

\section{KESIMPULAN}

Banyaknya kasus penolakan pemakaman jenazah Covid-19 menjadi sebuah permasalahan baru di tengah situasi pandemi. Hal ini dipicu oleh adanya rasa takut dari masyarakat akan tertular virus tersebut. Fenomena ini tentu memerlukan sebuah sosialisasi sekaligus edukasi yang efektif terhadap masyarakat. Berdasarkan hasil perancangan di atas, dapat disimpulkan bahwa penyampaian informasi mengenai tidak adanya dampak negatif dari pemakaman jenazah Covid-19 salah satunya dapat dilakukan melalui kampanye sosial dengan media motion graphics. 
Kampanye sosial stop tolak jenazah korban Covid-19 dilakukan melalui 3 tahapan yaitu praproduksi, produksi, dan pascaproduksi. Pada tahapan praproduksi dilakukan pencarian inspirasi, tahapan brainstorming yang menghasilkan konsep perancangan, serta pembuatan storyboard. Setelah itu dilaksanakan tahapan produksi yaitu pembuatan ilustrasi, lalu dianimasikan menggunakan teknik motion graphics. Setelah menyelesaikan tahapan produksi lalu dilakukan tahapan pascaproduksi. Pada tahapan pascaproduksi dilakukan penggabungan scene, pengisian suara, pengisian efek suara, dan juga musik. Setelah itu yang terakhir dilakukan pada tahapan pascaproduksi adalah proses rendering dan pendistribusian media ke Youtube, Facebook, maupun Instagram.

Perancangan motion graphics ini dapat memberikan edukasi bagi masyarakat agar tidak menolak atau lebih terbuka terhadap pemakaman jenazah Covid-19 di sekitar mereka, serta meningkatkan peran masyarakat untuk saling memberikan informasi terkait SOP pemulasaran jenazah Covid19. Perancangan motion graphics ini diharapkan dapat berkontribusi terhadap ilmu pengetahuan sebagai wacana baru tentang metode penyampaian sosialisasi informasi melalui media motion graphics. Dengan adanya perancangan ini diharapkan pula dapat memicu adanya perancangan atau penelitian lanjutan ke depannya seperti penggunaan motion graphics sebagai sarana sosalisasi program vaksinasi Covid-19 atau sarana edukasi lainnya.

\section{PERNYATAAN PENGHARGAAN}

Terimakasih kepada LPPM Insitut Teknologi Telkom Purwokerto yang telah mendukung secara finansial penelitian ini. 


\section{DAFTAR PUSTAKA}

Anggito, A. dan Setiawan, J. (2018) Metodologi Penelitian Kualitatif. Sukabumi: CV . Jejak.

Aprilia, D. P., Iswidayati, S. dan Triyanto (2019) 'Catharsis: Journal of Arts Education Creative Thinking Process of Mice Cartoon Creation in Harian Rakyat Merdeka the Period of 2019 Presidential Election', CATHARSIS, 8(3), pp. 239-248. Available at: http://journal.unnes.ac.id/sju/index.php/catharsis

Badan Pembinaan Hukum Nasional. (1984) Undang-undang nomor 4 tahun 1984 tentang wabah penyakit menular. Available at: https://bphn.jdihn.go.id/dokumen/view?id=861

Banjarnahor, S. (2020) 'Variasi Gejala Covid-19 yang Dialami Perawat Murni Teguh Memorial Hospital', Indonesian Trust Health Journal, 3(2), pp. 360-363. doi: 10.37104/ithj.v3i2.60.

Fajri, R. H., Zubaidah dan Pebriyeni, E. (2018) 'Perancangan Motion Graphic Sebagai Iklan Layanan Masyarakat Pentingnya Imunisasi Bagi Anak Usia Dini di Kota Bukittinggi', DEKAVE : Jurnal Desain Komunikasi Visual, 7(2). Available at: http://ejournal.unp.ac.id/index.php/dkv/article/view/9308

Hananto, B. A. (2020) 'Tinjauan Tipografi dalam Konteks industri 4.0', Seminar Nasional Desain dan Arsitektur (SENADA) 2020, 3, pp. 132-139. Available at: https://eprosiding.stdbali.ac.id/index.php/senada/article/view/278.

Herdiansyah, H. (2010) Metodologi Penelitian Kualitatif untuk IImu-ilmu Sosial. Jakarta: Salemba Humanika.

Kasali, R. (2007) Manajemen Periklanan. Jakarta: Pustaka Utama Grafiti.

Mahardhika, S. dan Fathoni, A. F. C. A. (2013) 'Storyboard dalam Pembuatan Motion Graphic', Humaniora, 4(2), pp. 1183-1189. doi: 
10.21512/humaniora.v4i2.3560.

Manihuruk, M. F. (2020) 'Penegakan Hukum dan Hak Asasi Manusia dengan

Paradigma Pancasila Terhadap Tindakan Penolakan Pemakaman Jenazah Korban COVID - 19', Christian Humaniora, 4(2), pp. 40-52.

McCloud, S. (2001) Understanding Comics: The Invisible Art (Memahami Komik). Jakarta: Gramedia Pustaka utama.

Nadya dan Erlyana, Y. (2020) 'Perancangan Video Animasi Infografis "Cara Urban Gardening Yang Tepat Untuk Wilayah Kota Dki Jakarta"', Desain Komunikasi Visual, Manajemen Desain dan Periklanan (Demandia), 5(2), pp. 348-369. doi: 10.25124/demandia.v5i2.2652.

Octavia, D. dan Fadilla, A. N. (2017) 'Perancangan Kampanye Sosial Pencegahan Kanker Serviks Terhadap Remaja Wanita Di Kota Jakarta', Desain Komunikasi Visual, Manajemen Desain dan Periklanan (Demandia), 2(02), pp. 200-215. doi: 10.25124/demandia.v2i02.935.

Patrycia, Z. (2013) 'Pengaruh Warna Bagi Suatu Produk dan Psikologis Manusia', MINDJournal, 3(1), pp. 31-48.

Perdana, S. A. dan Zubaidah (2020) 'Iklan Layanan Masyarakat Tentang Nomophobia Dengan Teknik Motion Graphic', DEKAVE : Jurnal Desain Komunikasi Visual, 10(1). Available at: http://ejournal.unp.ac.id/index.php/dkv/article/view/110827

Pujiyanto (2013) Iklan Layanan Masyarakat. Yogyakarta: Penerbit ANDI.

Rahmando, R., Syafwandi dan Trinanda, R. (2018) ‘Perancangan Iklan Layanan Masyarakat Keselamatan di Perlintasan Kereta Api Dalam Media Motion Graphic', DEKAVE : Jurnal Desain Komunikasi Visual, 7(2), pp. 3-15. Available at: http://103.216.87.80/index.php/dkv/article/view/9096

Rawlinson, J. G. (2017) Creative Thinking and Brainstorming. New York: Routledge. 
Sarwono, J. dan Lubis, H. (2007) Metode Riset untuk Desain Komunikasi Visual. Yogyakarta: Penerbit ANDI.

Satuan Tugas Penanganan COVID-19 (2020) Peta Sebaran / Satgas Penanganan COVID-19, www.covid19.go.id. Available at: https://www.covid19.go.id/peta-sebaran

Wardhani, R. K. dan Sudjudi, I. (2014) 'Perancangan Video Dokumenter Autisme', Jurnal Tingkat Sarjana Bidang Seni Rupa dan Desain, 1(1), pp. 1-9.

Zain, F. M. (2020) Jenazah Ditolak Warga, Bupati Banyumas Pimpin Pemindahan Makam Pasien Positif Covid-19, KOMPAS.com. Available at:

https://regional.kompas.com/read/2020/04/01/15004441/jenazahditolak-warga-bupati-banyumas-pimpin-pemindahan-makam-pasienpositif

Zikmund, W. G. dan Babin, B. J. (2011) Menjelajahi Riset Pemasaran. Jakarta: Salemba Empat. 